\title{
WPLYW MEDIÓW NA KREOWANIE WIZERUNKU STAROŚCI W REKLAMIE TELEWIZYJNEJ - BADANIE PILOTAŻOWE
}

\author{
KINGA KOWALEWSKA
}

\begin{abstract}
The purpose of the article is to find the answer to the questions whether television commercials have an impact on creating the image of the elderly and what image of old age and lifestyle of the elderly is built on the basis of television ads. Studies have confirmed the hypothesis and have shown that the media through the content presented in TV commercials have a real impact on the shape of the image of the elderly population. The results allow the media to be seen as strong and efficient tools in the process of creating the image as such, also of other populations or individuals. The qualitative results have shown that the image of old age is seen mainly as positive and neutral, whereas their lifestyle is perceived as real, idealized and attractive.
\end{abstract}

Key words: image, TV commercial, old age, the elderly

Według Stanisława Puppla (2016: 118-119) każda jednostka ludzka, a także zbiorowość, podlega „prawu powszechności wizerunku”, czyli posiada świadomość dotyczącą swojego obrazu i jest wyposażona w narzędzia, którymi za pomocą podejmowanych działań wytwarza wizerunek. Wytwarzanie wizerunku polega na wywoływaniu u odbiorcy „określonych wrażen” (Puppel, 2016: 111), a miarą skuteczności w zakresie działalności wizerunkowej każdej jednostki jest ,polityka wizerunku". Dotyczy ona istnienia każdego bytu ożywionego (zarówno do pojedynczych jednostek, jak i jednostek o charakterze zbiorczym) i opiera się na dwóch zasadach: zasadzie silnej obecności wizerunku i zasadzie długiego trwania wizerunku (Puppel, 2016: 119). Siła obecności wizerunku wynika z „maksymalnie usilnionych parame- 
trów (...) stosowanych przez komunikatorów w wytwarzaniu danego wizerunku", a długotrwałość wizerunku dotyczy ,przedłużonego wymiaru czasowego tej obecności" (Puppel, 2016: 119). W warunkach komunikacji naturalnej, polityka wizerunku realizowana jest mniej lub bardziej spontanicznie, podczas gdy w przekazach medialnych, a w szczególności w obszarze komunikacji marketingowej oraz PR, budowanie wizerunku marki, instytucji, całej populacji czy poszczególnych jednostek oparte jest na zaplanowanym, świadomym i długotrwałym działaniu podejmowanym w ogólnodostępnej przestrzeni publicznej (zob. Kowalewska, 2012). Stąd, na przykład w reklamie telewizyjnej silna obecność wizerunku osób starszych polega na m.in. wykorzystaniu głęboko zakorzenionych w danej kulturze stereotypów czy zatrudnianiu w roli osób starszych znanych aktorów. Z kolei długie trwanie zapewnia reklamie wysoka częstotliwość transmisji danego przekazu. W ten sposób, realizując podstawowe zasady polityki wizerunku, reklama telewizyjna przyczynia się do kreowania wizerunku osób starszych.

Reklamę w niniejszej pracy rozumie się jako „formę płatnej, bezosobowej komunikacji, odbywającej się za pośrednictwem mediów, o perswazyjnym charakterze, mającej na celu ukazanie produktu/marki/usługi w pozytywnym świetle" (Kowalewska, 2017a: 230). Reklama telewizyjna uznawana jest za jedną z najbardziej skutecznych (komunikacyjnie i marketingowo) typów przekazów reklamowych. Oddziałując na kilka zmysłów jednocześnie skupia uwagę odbiorcy, daje możliwość precyzyjnego przedstawienia promowanego produktu, a przede wszystkim ma możliwość dotarcia do bardzo dużej liczby odbiorców w bardzo krótkim czasie (Kowalewska, 2018a: 72). Z komunikacyjnego punktu widzenia, reklama telewizyjna to hybryda komunikacyjna, obejmująca tekst (modalność wizualna i słuchowa) oraz ikonę (modalność wizualna). Biorąc pod uwagę wizerunkowe strategie modalnościowe, telewizyjne przekazy reklamowe wykorzystują strategie hybrydowe, czyli „oparte na wykorzystaniu wszystkich możliwych i dostępnych człowiekowi modalności sensorycznych z użyciem nośników technologicznych" (Puppel, 2016: 117). Tym samym, wizerunek osób przedstawionych w telewizyjnych przekazach reklamowych budowany jest na podstawie zarówno realizacji warstwy językowej, jak i ikonicznej/obrazowej (por. Kowalewska, 2017a: 231) przy wykorzystaniu uwarunkowań nie tylko biologicznych, ale też społecznych i kulturowych (Kowalewska, 2018b: 56). Cechy formalne reklamy telewizyjnej takie jak długość jej trwania, formuła, narzucona skrótowość, prowadzą do pewnej koniecznej schematyczności formy oraz sposobu ukazywania osób i wydarzeń. Cel tych zabiegów przedstawiają Szyszka i Walotek-Ściańska (2013: 92), którzy piszą, że:

charakter przekazu zakłada odpowiednie projektowanie komunikatów i „świata przedstawionego" wraz z jego bohaterami, zgodnie z uogólnionymi społecznymi oczekiwaniami oraz wyobrażeniami. W przekazie reklamowym, zwłaszcza telewizyjnym, kierowanym do homogenicznego odbiorcy, chodzi o to, by jak najszersza grupa odbiorców zrozumiała komunikat oraz mogła utożsamić się z zawartym w niej obrazem rzeczywistości. 
Najczęściej stosowaną strategią komunikacyjną umożliwiającą szybką identyfikację określonego typu postaci oraz wydarzeń, a także utożsamianie się z wybranymi postaciami jest stereotypizacja (Abbate, Boca i Bocchiaro, 2004). Wykorzystując stereotypizację zarówno pozytywną, jak i negatywną, reklama „najczęściej bazuje na tych wypracowanych w różnych kontekstach i sytuacjach społecznych - staje się więc schematycznym odbiciem rzeczywistości, uproszczonym i uogólnionym obrazem funkcjonujących w danej społeczności przekonań i opinii”" (Szyszka i Walotek-Ściańska, 2013: 92; por. Kozłowska, 2006). W związku z powyższym, w przekazach reklamowych dochodzi do marginalizowania rzeczywistego obrazu starości na rzecz wizerunku spolaryzowanego na podstawie istniejących stereotypów:

Z jednej strony dominuje pozytywny, lecz nieautentyczny obraz ,aktywnego seniora” zbudowany w oparciu o wartości charakterystyczne dla młodości (estetyka, witalność, zdrowie), stereotyp ten obecny jest przede wszystkim w reklamie i przekazach promocyjnych. $Z$ drugiej strony dominuje stereotyp negatywny, seniorów pasywnych, schorowanych, wymagających pomocy, borykających się z problemami finansowymi (Szyszka i Walotek-Ściańska, 2013: 97).

Za pomocą stereotypów negatywnych tworzy się wizerunek oparty na definiowaniu starości głównie przez pryzmat deficytów: zdrowia, niezależności, urody, energii, czy środków finansowych, gdzie atrybutami osób starszych stają się „,siwe włosy, pomarszczona skóra, zgięte w pałąk plecy czy laska" (Stefaniak-Hrycko, 2012: 89). Natomiast wykorzystanie stereotypów pozytywnych prowadzi do postrzegania osób starszych jako walczących z objawami starości we wszystkich ich wymiarach m.in. zdrowotnym czy estetycznym, lub troskliwych opiekunów swoich wnuków (Pawlina, 2012: 105). Taki stereotypowy sposób przedstawiania postaci osób starszych w przekazach telewizyjnych silnie przekłada się na ukazywany przez nich styl życia i podejście do samej starości.

Wyniki prowadzonych dotychczas badań dotyczących wizerunku starości oraz osób starszych kreowanego na podstawie telewizyjnych przekazów reklamowych wskazują, że zarówno wśród młodzieży na poziomie szkoły podstawowej, jak i młodych dorosłych, wizerunek starości określany jest jako negatywny, natomiast wizerunek osób starszych - pozytywny (Kowalewska, 2018c; 2018d; 2018e). W kategoriach ilościowych, badanie porównawcze, dotyczące m.in. częstotliwości pojawiania się reklam prasowych z udziałem osób starszych w roku 2012 i 2016 wykazały spadek, zmniejszyła się także liczba reklam z udziałem starszych celebrytów (Kowalewska, 2017b). Z kolei badanie o zasięgu międzynarodowym, w którym na podstawie analizy zawartości porównywano wizerunek osób starszych w telewizyjnych przekazach reklamowych w Polsce i w USA wykazało, że w analizowanej próbie reklam emitowanych w Polsce większość spotów przedstawiała pozytywny wizerunek osób starszych (60\%), podczas gdy w amerykańskich reklamach domi- 
nował wizerunek neutralny (67\%) (Kowalewska i Grodzki, 2019: 111). Ciekawostką jest, że żaden $\mathrm{z}$ badanych przekazów nie prezentował negatywnego wizerunku seniora.

\section{Metodologia badania}

Celem badania była próba znalezienia odpowiedzi na następujące pytania ogólne:

- czy treść telewizyjnych komunikatów reklamowych ma wpływ na kreowanie wizerunku osób starszych w świadomości odbiorców,

- jaki wizerunek starości i stylu życia osób starszych budowany jest na podstawie telewizyjnych komunikatów reklamowych w świadomości odbiorców dorosłych.

Założono, że obraz starości i stylu życia osób starszych przedstawionych w telewizyjnych komunikatach reklamowych ma wpływ na kształtowanie się ich wizerunku u odbiorców tych przekazów.

Za metodę badania przyjęto sondaż diagnostyczny, który według Pilcha i Bauman (2010: 79-80) jest odpowiedni do badania „stanów świadomości społecznej, opinii i poglądów określonych zbiorowości”. Narzędziem badawczym był autorski kwestionariusz ankiety składający się z 5 pytań o charakterze zamkniętym; Pyt. 1, 2, 4 i 5 to pytania jednokrotnego wyboru, a Pyt. 3 - wielokrotnego. Wyniki badania zostały graficznie zwizualizowane $\mathrm{w}$ formie wykresów i podane $\mathrm{w}$ wartościach procentowych.

Badanie pilotażowe przeprowadzono w 2018 roku na grupie osób należących do populacji osób dorosłych, jednak ,nie starszych”. Intencjonalny dobór próby badawczej miał na celu zebranie opinii od ankietowanych, którzy nie posiadają jeszcze doświadczeń z własnej starości i dzięki temu ich opinie będą mogły być uznane za bardziej obiektywne.

Początkowo baniem objęto 379 osoby. Jednak przed przystąpieniem do opracowywania wyników badań uwzględniono odpowiedzi na pytanie: $C z y$ zdarza ci się oglądać reklamy telewizyjne? Spośród wszystkich ankiet, w których badani mieli do wyboru odpowiedzi takie jak: często, czasami, nie mam zdania, rzadko, nigdy, usunięto wszystkie, w których ankietowani wybrali odpowiedź „nigdy” - łącznie 7 ankiet.

Stąd, wyniki badań dotyczą 372 osób pomiędzy 19 a 50 rokiem życia, z czego do przedziału wiekowego 19-29 lat należą 323 osoby, 30-39 lat - 28 osób i 40-50 lat - 21 osób. W kategorii płci, próba badawcza składała się z 325 kobiet oraz 47 mężczyzn.

Wszystkie prezentowane poniżej wyniki są rezultatem badań własnych autorki. 


\section{Wyniki badania}

Czy zdarza Ci się ogladać reklamy telewizyjne?

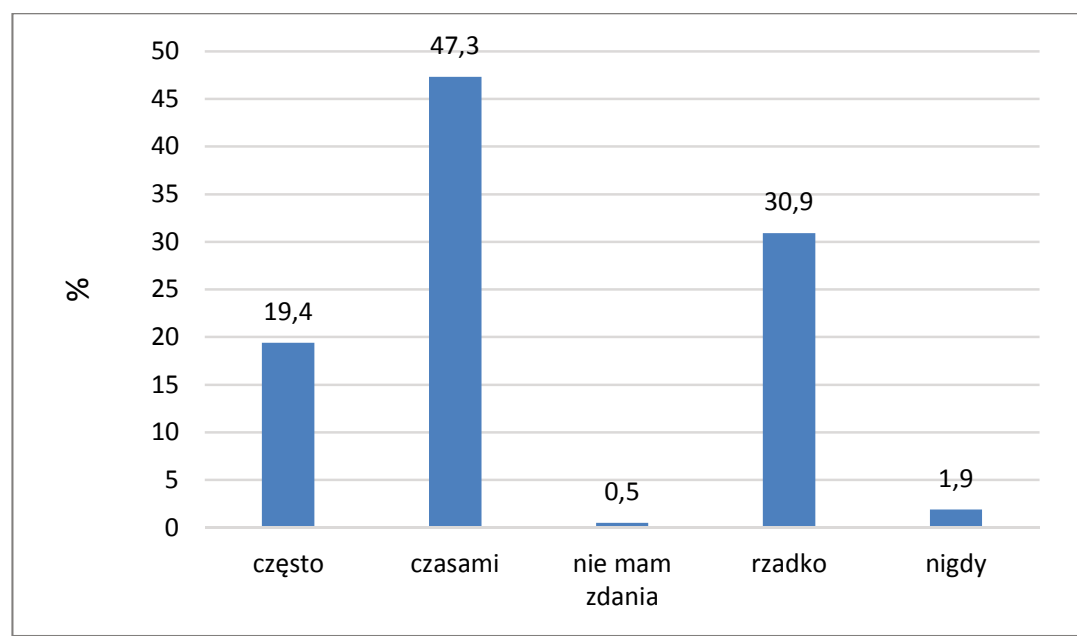

Wykres 1. Częstotliwość oglądania reklam telewizyjnych wśród badanych

Biorąc pod uwagę fakt, iż od kilku lat konsekwentnie spada oglądalność telewizji odpowiedzi na pytanie dotyczące częstotliwości oglądania reklam telewizyjnych są dość zaskakujące. Łącznie, ponad $97 \%$ badanych to odbiorcy telewizyjnych komunikatów reklamowych (zob. Wykres 1.). Odpowiedzi „często” i „czasami” udzielone na to pytanie świadczą o wysokiej ekspozycji badanych na ten typ komunikatów - prawie połowa ankietowanych przyznaje, że ogląda reklamy telewizyjne czasami, a co piąta osoba często. Jedynie niecałe $2 \%$ ankietowanych deklaruje, że nigdy nie staje się odbiorcą reklam telewizyjnych.

Pytanie o obecność tendencji wzrostu liczby reklam telewizyjnych z udziałem osób starszych miało na celu ustalenie czy na poziomie świadomym odbiorcy zauważają różnicę w liczbie spotów przedstawiających osoby starsze. Różnica ta może mieć dwojaki charakter - jakościowy oraz ilościowy. W sensie jakościowym zwiększeniu może ulec liczba różnych spotów dotyczących coraz większej palety produktów czy usług, natomiast w sensie ilościowym może dotyczyć jedynie zwiększenia częstotliwości emitowania tych samych przekazów niosących dokładnie tą samą treść. Pierwsza sytuacja prowadzi do zróżnicowania wizerunkowego, druga do wzmocnienia danego wizerunku, przy czym obie sprzyjają wprowadzeniu i utrwaleniu wizerunku osób starszych w świadomości odbiorców.

Zdecydowana większość odpowiedzi (ponad 73\%) wskazuje na zauważalną obecność tendencji wzrostu liczby reklam z udziałem osób starszych, podczas gdy niespełna $16 \%$ jej nie dostrzega (zob. Wykres 2.). Co dziesiąty badany $(11,0 \%)$ nie ma zdania na ten temat. 
Czy Twoim zdaniem w ciagu ostatnich kilku lat zwiększyła się liczba telewizyjnych komunikatów reklamowych z udziatem osób starszych?

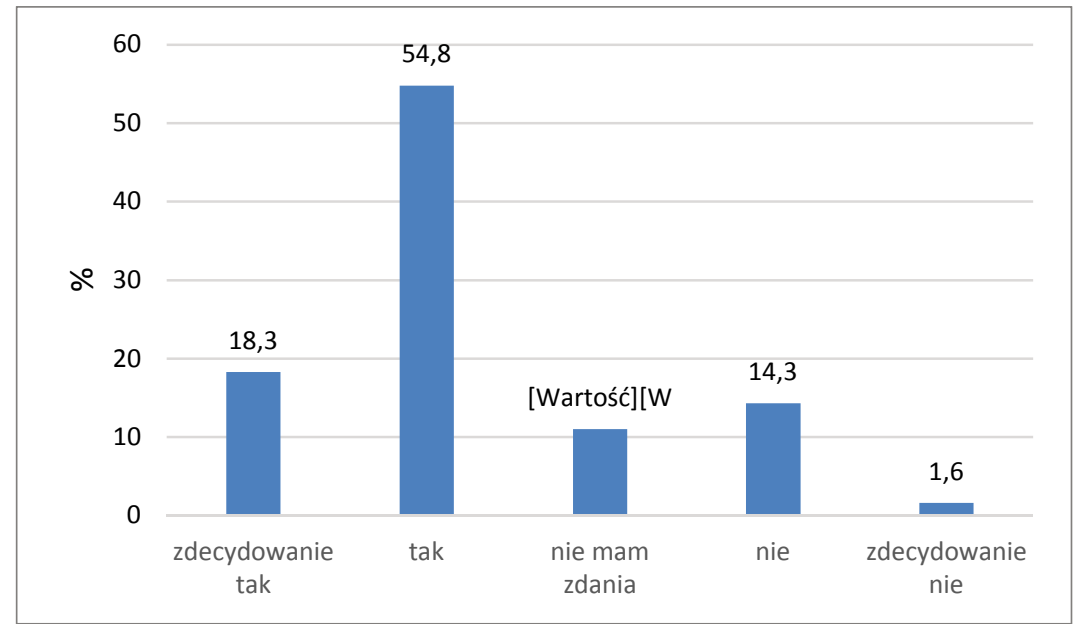

Wykres 2. Obecność tendencji wzrostu liczby reklam z udziałem osób starszych

Jaki jest styl życia osób starszych ukazywany w telewizyjnych komunikatach reklamowych?

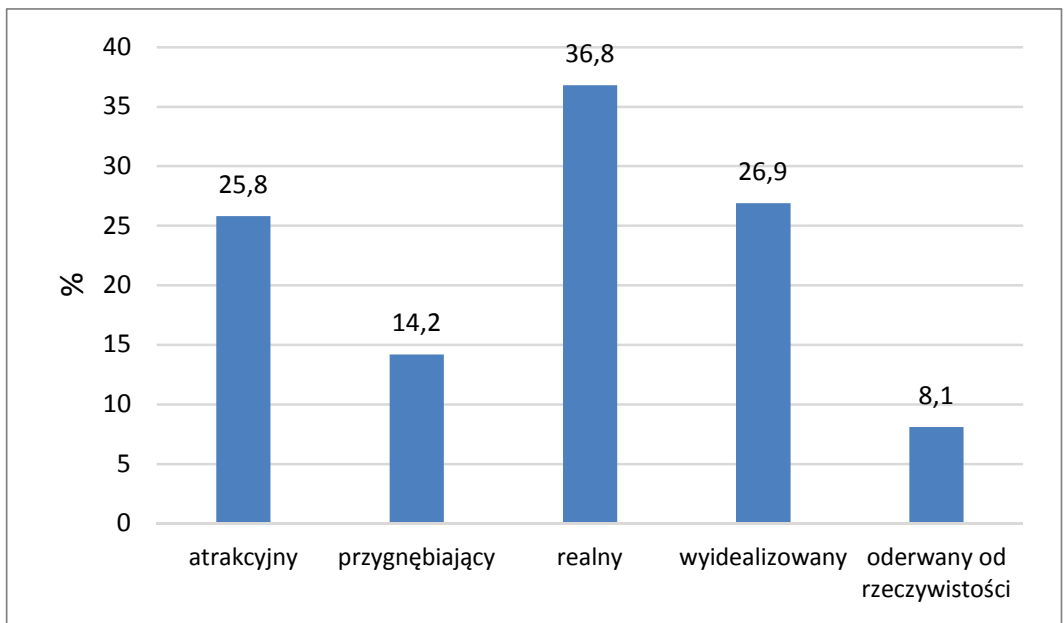

Wykres 3. Styl życia osób starszych ukazywany w telewizyjnych komunikatach reklamowych* * podane wartości nie sumują się do $100 \%$ ze względu na możliwość wielokrotnego wyboru odpowiedzi

Stosunkowo wysoki odsetek badanach deklaruje, że styl życia osób starszych ukazany w reklamach telewizyjnych jest ,realny” (ponad 36\%), czyli w dość wierny sposób oddaje realia życia osób starszych w Polsce (zob. Wykres 3.). „Realność” 
przedstawianych treści jest jedną z kluczowych elementów z punktów widzenia agencji reklamowych i zatrudnionych w nich specjalistów, jako że dzięki podobieństwu przedstawionych osób i sytuacji do realnego życia odbiorca może się prezentowanymi postaciami utożsamić, co czyni cały przekaz bardziej wiarygodnym. Co ciekawe, co czwarty ankietowany uważa styl życia osób starszych przedstawiony w reklamie telewizyjnej za ,atrakcyjny” i prawie taka sama liczba osób za ,wyidealizowany”. Należy zaznaczyć, że atrakcyjność może wynikać właśnie z wyidealizowania na potrzeby marketingowe. Niemniej, pewna liczba badanych (ponad 14\%) postrzega przedstawiany styl życia jako przygnębiający i ta obserwacja także jest słuszna zważywszy na fakt, że zdecydowana większość przekazów reklamowych ma na celu promowanie produktów farmakologicznych i wyrobów leczniczych, w związku z czym w sposób naturalny porusza tematykę problemów zdrowotnych związanych z zaawansowanym wiekiem i starzeniem się organizmu (Stefaniak-Hrycko, 2012; Kowalewska, 2017b). Jako „oderwany od rzeczywistości” ocenia styl życia osób starszych prezentowany w telewizyjnych przekazach reklamowych około $8 \%$ badanych.

Jaki jest wizerunek starości kreowany przez media na podstawie telewizyjnych komunikatów reklamowych?

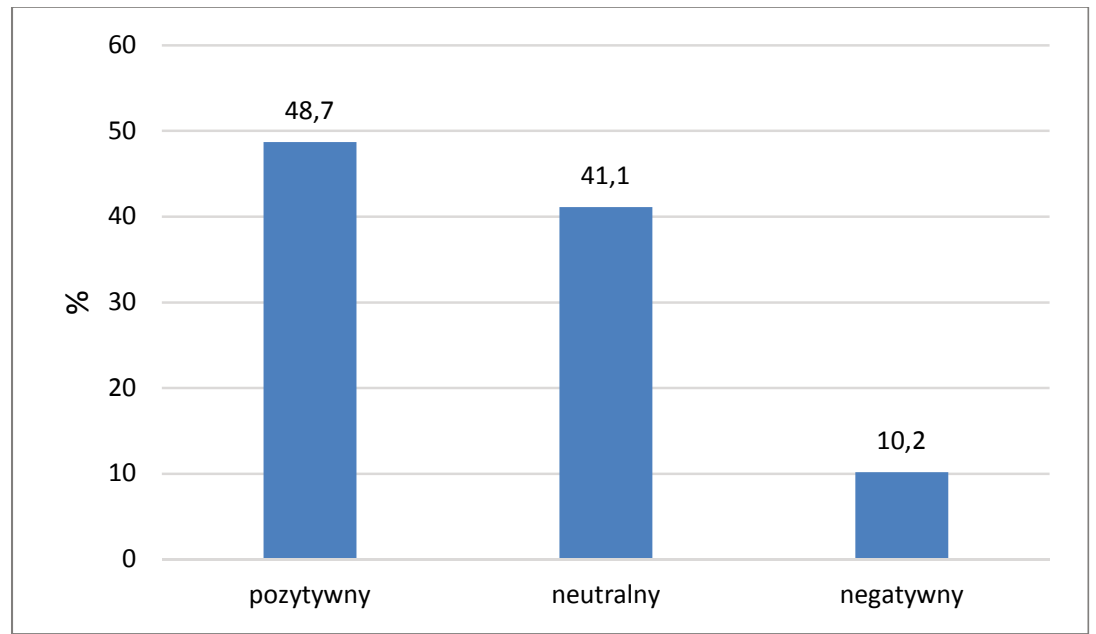

Wykres 4. Charakter wizerunku starości kreowany w telewizyjnych komunikatach reklamowych*

* podane wartości nie sumują się do $100 \%$ ze względu na możliwość wielokrotnego wyboru odpowiedzi

Odpowiedzi na pytanie dotyczące charakteru wizerunku starości kreowanego przez media na podstawie telewizyjnych komunikatów reklamowych są konsekwentne w stosunku do odpowiedzi na poprzednie pytanie (por. Wykres 3. i Wykres 4.). 
Blisko połowa ankietowanych (48,7\%) uważa, że kreowany wizerunek ma charakter pozytywny. Także wysoki odsetek badanych (ponad 40\%) opisuje wizerunek osób starszych w reklamach telewizyjnych jako nienacechowany - „neutralny”. Tylko co 10 osoba postrzega go jako ,negatywny”.

Najistotniejsze, z punktu widzenia przyjętej perspektywy badawczej było zbadanie, czy w opinii ankietowanych media mają zdolność wpływania na wizerunek osób starszych, jaki buduje się w świadomości odbiorców na podstawie treści przedstawionych $\mathrm{w}$ telewizyjnych komunikatach reklamowych. Okazuje się, że ponad $60 \%$ ankietowanych jest zdania (,zdecydowanie tak” i „tak”), że treść komunikatów reklamowych ma realny wpływ na kształt wizerunku populacji osób starszych wśród osób będących odbiorcami - widzami (zob. Wykres 5.). Jednocześnie, stosunkowo wysoki odsetek badanach (ponad 30\%) deklaruje brak zdania na zadany temat, co sugeruje, że nie są w stanie jednoznacznie określić, czy rzeczywiście media mogą taki wpływ wywierać. Niespełna $6 \%$ ankietowanych uważa, że odbiorca telewizyjnych treści reklamowych nie pozostaje pod wpływem przekazu (,nie” i „ zdecydowanie nie"), jeśli chodzi o kształtowanie wizerunku osób starszych.

Czy Twoim zdaniem media poprzez reklamę telewizyjna kreuja wizerunek osób starszych?

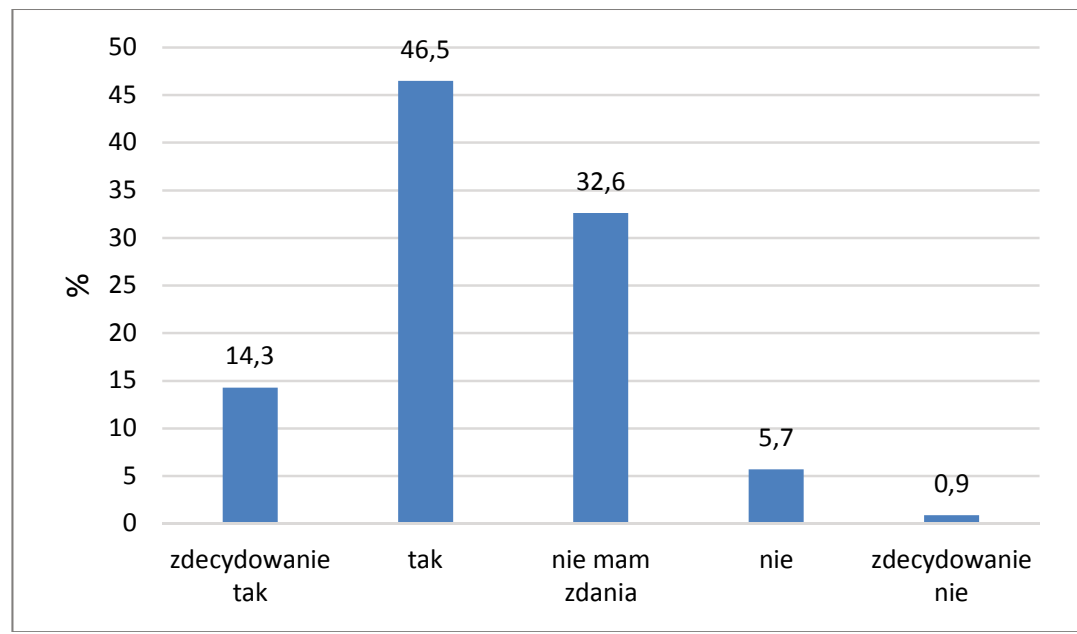

Wykres 5. Zdolność mediów do kreowania wizerunku osób starszych

\section{Podsumowanie i wnioski}

Przede wszystkim przeprowadzone badania pilotażowe potwierdziły hipotezę i wykazały, że zdaniem ankietowanych media poprzez treść przedstawioną w telewizyjnych komunikatach reklamowych realnie wpływają na kształt wizerunku popu- 
lacji osób starszych wśród odbiorców. Tak kształtujące się wyniki pozwalają widzieć media jako silne i sprawcze narzędzia w procesie kreowania wizerunku jako takiego, także innych populacji czy jednostek.

Badani wskazali bardzo wyraźnie na zauważalny wzrost liczby telewizyjnych komunikatów reklamowych przedstawiających osoby starsze w ciągu ostatnich kilku lat. Zgodnie z teorią polityki wizerunku zaproponowaną przez Puppla (2016) wraz ze wzrostem częstotliwości odbioru danego komunikatu wrasta siła wizerunku kreowanego na jego podstawie. Biorąc zatem pod uwagę także fakt, że 97\% badanych określiło się jako odbiorcy reklam telewizyjnych w częstotliwości „często” i „czasami”, można wnioskować, że wizerunek powstały w wyniku ekspozycji na treści komunikatów reklamowych będzie miał charakter silny o wysokim natężeniu.

Wyniki dotyczące jakościowego charakteru wizerunku starości stoją w sprzeczności z wynikami poprzednich badań autorki w innych środowiskach, np. wśród młodzieży dorastającej oraz dorosłej w środowisku zarówno miejskim jak i wiejskim (Kowalewska 2018c, 2018d, 2018e), według których wizerunek starości prezentowany $w$ telewizyjnych komunikatach reklamowych postrzegany był przez badanych jako negatywny. Zauważona rozbieżność wyników wskazuje na konieczność podejmowania dalszych badań w tym obszarze.

\section{Bibliografia}

Abbate, C.S., Boca S. i P. Bocchiaro. 2004. „Stereotypes in persuasive communication: influence exerted by a disapproved source". Journal of Applied Social Psychology 34.6. 1191-1207.

Kowalewska, K. 2012. "Billboard advertising in a context - an ecological perspective". W zbiorze: Koszko, M., Kowalewska, K., Puppel, J. i E. Wąsikiewicz-Firlej. (red.). Lingua: nervus rerum humanarum. Poznań: Wydawnictwo Naukowe UAM. 223-238.

Kowalewska, K. 2017a. „Wizerunek osób starszych w medialnych przekazach reklamowych - analiza własna na podstawie wybranych reklam w prasie kobiecej w Polsce". W zbiorze: Wszołek, M. (red.) Teorie komunikacji i mediów 10. Konstruowanie komunikacji i mediów 2. Wrocław: Wydawnictwo LIBRON. 227-246.

Kowalewska, K. 2017b. "The demographic trends and the presence of the elderly in Polish press advertising in 2012 and 2016 - a comparative study." Hygeia Public Health 52.2. 183-189.

Kowalewska, K. 2018a. The perception of language and non-language resources in press advertisements: an ecolinguistic-communicative approach. Poznań: Wydawnictwo Naukowe UAM.

Kowalewska, K. 2018b. "The role of non-verbal cues in image making on the basis of selected press advertisements showing elderly women". Scripta Neophilologica Posnaniensia XVIII. 55-65.

Kowalewska, K. 2018c. „Wizerunek starości i osób starszych w oczach dorastającej młodzieży - komunikat z badań". Chowanna 1.50. 275-302.

Kowalewska, K. 2018d. „Wizerunek starości i osób starszych wśród uczniów na poziomie szkoły podstawowej”. Studium Vilnense A XV. 146-151.

Kowalewska, K. 2018e. „Postrzeganie starości i osób starszych w rodzinie przez dorastającą młodzież w środowisku wiejskim". Wychowanie w rodzinie 18.2. 277-305. 
Kowalewska, K. i E. Grodzki. 2019. „The representation of mature adults in TV commercials: a crosscultural content analysis of portrayals in Poland and the U.S.". Annales. Ethics in Economic Life 22.1. 103-118.

Kozłowska, A. 2006. Reklama. Socjotechnika oddziaływania. Warszawa: Oficyna Wydawnicza SGH.

Pawlina, A. 2010. „Sposoby prezentowania osób starszych w reklamie. Analiza wybranych zagadnień”. Zeszyty naukowe nr 8 Wyższej Szkoty Ekonomicznej w Bochni 1. 99-115.

Puppel, S. 2016. „Kuźnia Hefajstosa czyli krótki zarys teorii wizerunku w komunikacji człowieka”. Scripta Neophilologica Posnaniensia XVI. 109-124.

Stefaniak-Hrycko, A. 2012. „Starość w reklamie telewizyjnej - śmieszy czy przeraża?” Nowiny Lekarskie 81(1). 89-95.

Szyszka, M. i K. Walotek-Ściańska. 2013. „Osoby starsze w środkach masowego przekazu”. W zbiorze: Walotek-Ściańska, K., Šerák, M., Szyszka, M. i Ł. Tomczyk. (red.). Starzenie się i starość w dynamicznie zmieniającym się świecie. Sosnowiec-Praha: Oficyna Wydawnicza Humanitas. 